The Canadian Journal of Higher Education, Vol. XXV-1, 1995

La revue canadienne d'enseignement supérieur, Vol. XXV-1, 1995

\title{
Success Community College: An Examination of Organizational Change
}

\author{
JOHN S. LEVIN*
}

\section{Abstract}

An examination of organizational change was carried out at a community college where there was evidence of events which might precipitate change, including events such as leadership succession, new management and governance structures, and proposed cultural shifts. The college during a prolonged period experienced considerable growth in personnel, in facilities, and in students. The beginning of this period coincided with presidential succession, and the period itself was accompanied by a sizable turnover of administrative personnel (approximately 60\%, or 10 of 16, of educational administrators). These factors provide the conditions for organizational change, certainly to the extent that "change refers to alterations in the allocation of resources, distribution of power, and the internal structure of the organization" (Hasenfeld 1983, p. 219). While change can lead to organizational success, on another level these changes can result in the victimization of organizational members. This case indicates that not all organizational change has a happy ending, and that those who promote and facilitate the change process for community colleges should consider all potential outcomes of change, including the victimization of organizational participants.

* University of Arizona

The author is grateful to Dr. Graham Kelsey, University of British Columbia, for his thoughtful suggestions on an earlier version of this article. 


\section{Résumé}

Nous avons conduit cette analyse des changements de structure au sein d'un collège communautaire alors que s'y produisait un certain nombre d'événements: changement de direction, renouvellement des cadres et des structures de gouvernement, propositions d'aménagements des orientations culturelles. Sur une période relativement longue, ce collège a permis d'enregistrer une croissance importante du nombre des inscriptions, la croissance des effectifs en personnel de soutien et une expansion appréciable de la surface de ses installations. Le début de cette période coïncidait avec un changement à la présidence, qui s'accompagna d'un renouvellement important du personnel administratif - 10 membres sur 16, soit $60 \%$ du personnel administratif en charge de l'éducation. Ces facteurs pris dans leur ensemble contribuent assurément à une modification importante de l'organisation si tant est que "le répartition des responsabilités et de la structure interne de l'organisation.” (Hasenfeld, 1983, p. 219). Si ces modifications peuvent effectivement se traduire par un taux de réussite au niveau de l'organisation, elles peuvent entraîner par ailleurs la marginalisation de membres de cette organisation. Cette étude révèle que tous changements de structures ne se terminent pas tous changements au niveau des collèges communautaires devraient tenir compte de l'ensemble des conséquences qu'entraînent ces changements, y compris la marginalisation d'un certain nombre de membres de l'organisation.

\section{Introduction}

Organizational change is both promoted and lauded when change is directed, either by management or by a single, highly visible chief executive officer. In both popular and scholarly organizational literature, purposive change where there is a fundamental or enduring alteration (Beckhard \& Pritchard, 1992; Smith, 1982) is viewed as an action of creative leadership (Beckhard \& Pritchard, 1992). Managed organizational change, however, can and does lead to casualties in spite of the exhortations of writers who address the need for change or the success stories of organizations undergoing change. These changes are associated with costs often ignored in the accounts of success. Indeed, while change can lead to organizational success, on another level these changes can result in the victimization of organizational members. In this analysis, a president of a community college originated changes so sweeping and so fundamental that a post hoc analysis views these as efforts to change the culture of an organization. 
The development of community colleges suggests that these institutions have characteristics of organizations engaged in defining and articulating their mission, in establishing an identity, and in organizing and managing work (Bergquist, 1992; Cross, 1985; Dennison \& Gallagher, 1986). They are highly susceptible to forces of change, as well as institutions influenced by ideology and politics. Their lack of traditions (Cohen \& Brawer, 1982), their brief historical development (Dennison \& Gallagher, 1986; Deegan \& Tillery, 1985), their use as a social instrument by external influencers (Brint \& Karabel, 1989; Dennison \& Gallagher, 1986; Levin \& Dennison, 1989), and their cultural and managerial autonomy (Brint \& Karabel, 1989; Levin, 1992) correspond to the portrayal of community colleges as dynamic, fluid environments, with large potential for change. It is not surprising, then, that such events as leadership succession (Miskel \& Cosgrove, 1985), the introduction of new management and governance structures, and proposed cultural shifts (Cooper \& Kempner, 1991) would affect the community college.

\section{The Study of Change at Success Community College}

An examination of organizational change was carried out at a community college where there was evidence of actions and events which might precipitate change, including leadership succession, new management and governance structures, and proposed cultural shifts. A case study approach (Merriam, 1988), involving field research methods (Burgess, 1984), which relies upon participant observation and analysis and is supplemented by institutional, government, and public documents, was the principal method of exploring organizational change in the community college.

In justifying case studies, Chaffee and Tierney (1988) assert that to "understand colleges and universities as socially constructed organizations and discern what can make them effective" (pp. 12-13), intimate, daily contact with institutional life is a requisite. In this investigation, there was reliance upon the perceptions and experiences of institutional participants. Survey questionnaires and extended discussions with five former academic administrators provided participant data, and these data were analyzed and compared. Participant perceptions thus comprise a component of the total data. Additionally, the researcher observed, and participated in the events and actions of the college during the first four and one-half years of the study. The investigator served as a college administrator until 1991 when he left this college for an administrative position at another community college. During his administrative career at the college which is the subject of this investigation, the investigator collected data on 
college functioning and management, taking notes at meetings, where senior and mid-level administrators as well as the president were present. A second component, then, of data includes the notes and perceptions of the investigator as a participant in institutional life, particularly the administrative side of institutional life.

The investigator also collected institutional documents including those which were not for public distribution (e.g., memos between administrators) as well as government (e.g., planning) and public documents (e.g., newspaper articles on the college). Thus a third component of data for this study is derived from institutional and public documents.

The investigator participated in extended conversations with administrators, support staff, and faculty during his career at this site, and he initiated extended conversations with former and present faculty and administrators following his departure from the college. Therefore, information acquired through extended conversations with college administrators, faculty, and support staff over a nearly seven year period (1987-1994) was used to provide an historical account of events and a context for analysis of behaviours and actions.

The study begins with the arrival of a new college president in 1987 and concludes some six years later with the departure of the college president. The college under investigation is given the fictitious name "Success Community College" to preserve confidentiality. The name "Success" in this study is viewed as appropriate in that the emphasis of the new president was upon tangible outcomes such as growth in student numbers and increase in public recognition for the college. The college did, indeed, have success in these domains. At this college, the terms success, succeed, and successful were used frequently in college publications and in the promotion of the institution. From another perspective, however, and that employed throughout this study, the term success has ironic connotations.

Success Community College possesses numerous attributes compatible with a study of organizational change. Prior to the arrival of the new college president, Success Community College reflected organizational characteristics such as multiple and conflicting goals, indeterminate technologies, and looselycoupled internal structures, capacities identified by Hasenfeld (1983) which give rise to organizational change. The college is located within a government jurisdiction where considerable institutional autonomy permits differentiation among colleges (e.g., separate college boards, local collective bargaining, potential for considerable influence by the chief executive officer, and limited restrictions upon such institutional matters as technology, acquisition of resources, and internal structuring). The college during a prolonged period experienced considerable growth in personnel, in facilities, and in students. The beginning of this period coincided with presidential succession, and the period 
itself was accompanied by a sizable turnover of administrative personnel (approximately $60 \%$, or 10 of 16, of educational administrators). These factors provide the conditions for organizational change, certainly to the extent that "change refers to alterations in the allocation of resources, distribution of power, and the internal structure of the organization" (Hasenfeld, 1983, p. 219) and change which is fundamental (Beckhard \& Pritchard, 1992), as change areas include mission, identity and operations.

Institutional documents used in this study include college public documents (e.g., college calendar, committee meeting minutes, annual reports, budget and enrolment reports), memoranda circulated among administrators during this period, all written communication broadcast by the college president among administrators, faculty and support staff, and institutional reports which pertain to college positions on both internal and external matters (e.g., college reaction to government initiatives, community studies, facilities development of the college).

Extended discussions with former college administrators and survey questionnaires were carried out early in 1992. These seven administrators, of whom only five agreed to participate formally in the investigation, had already severed their employment relationship with Success Community College. The survey questionnaires asked respondents to discuss their experience of institutional change, their initial expectations of the college president, their perceptions of and relationship with other administrators including the college president, their views of effects of institutional actions upon board members, faculty, and support staff, their assessment of causes and determinants of organizational action, and their interpretation and assessment of outcomes of organizational action and change.

Extended discussions from 1987 to 1991 with administrators, faculty, support staff, and a governing board member involving the researcher included personal one-to-one conversations and group discussions. These focused upon organizational functioning, decision-making, and administrative behaviours, covering situations and interactions where the investigator was not present to observe.

Finally, and as noted earlier, the researcher observed organizational behaviour during the 1987-1991 period, taking notes during college meetings which involved college administrators.

It should also be pointed out that the college president was invited to participate in the study, at the same time as the other administrators, through an interview and survey questionnaire, but this invitation was not acknowledged and there was no response from the president to the invitation. Two other current college administrators were asked to complete survey questionnaires, but they did not respond to two separate invitations. It was reported to the investigator by a college administrative staff member that at a meeting with senior administrators, 
the president directed the administrative personnel not to respond to questionnaires for this study. A further account of the investigative process for this study is reported elsewhere (Levin, 1992).

The use of the perceptions of faculty and support staff as data sources was limited. Given the organizational climate during this period, which is described in later sections, faculty and support staff had little involvement in governance and management and thus had little first-hand knowledge of administrative behaviours or organizational decisions. As noted by one faculty member in 1994, "I figured that the only strategy was to do my job and collect my pay...attempts to...influence the direction of the college were a waste of energy". Another, in reflecting upon organizational behaviours during this period of investigation, stated "I tried to keep my head down when I couldn't see a clear gain from looking over the edge of the trench".

Following the departure of the president from Success Community College, new sources of data emerged for use by the investigator. These included the perceptions of administrators, faculty, and staff based upon several documents and institutional events. They also included newspaper accounts of the departure of the president and the rationale for that departure. Organizational participants provided data on a college self-study report (1992/93), an investigation conducted by independent consultants in 1993 of the performance of the president, the severance of relations between the board and the president, and the media coverage of the political aspects of events leading to the departure of the president. Newspaper accounts provided data to explain the process leading to the departure of the president, including statements from both the chair of the board as well as the college president.

Analysis of data followed qualitative approaches suggested by Miles and Huberman (1984) and Erickson (1986). On the one hand, data were used to establish a narrative line or sequence of events. On the other hand, data were compared and synthesized to establish common patterns and themes. From this data, a number of patterns and themes emerged both through an historical review of behaviours and actions and through the descriptions of institutional members in their conversations and in the responses of administrators to the survey questionnaire. It was clear from the data that the college president was the central determinant of institutional behaviours and action at Success Community College and that the topic of leadership succession was highly applicable to this study. As well, management and governance of Success Community College emerged as dominant themes in conversations and suggested that decision-making and organizational action were interconnected with the college president. Finally, the concept of cultural shift was most forceful in 
the conversations and in the responses of the five administrators who responded to the survey questionnaire. The data showed that the president intended to alter organizational life and organizational action, and the patterns of behaviour of organizational members altered significantly during this period. Furthermore, how members interpreted organizational life and how they behaved were intimately connected to the demands and behaviours of the college president.

\section{Discussion}

\section{Leadership Succession}

Succession is "a disruptive event [that] changes the line of communication, realigns relationships of power, affects decision making" (Miskel \& Cosgrove, 1985 , p. 88). The arrival of the new president at Success Community College was preceded by organizational instability during a two year period, involving presidential resignation and disaffection among college personnel. During this period, actions occurred which suggest a high degree of internal disruption. These actions included an internal college investigation, a faculty union vote of non-confidence in the performance of senior administrators, including the president, administrative resignations, and an institutional evaluation, as well as a major recruitment process for a new president (Institutional documents, newspaper articles). The new president had neither personal nor professional affiliation with the personnel of Success Community College, and was not part of the 'old guard'; thus, a sense of historical continuity was potentially at risk of loss with this presidential succession.

The installation of the new president coincided with both institutional growth and alterations in the external environment. College expansion, tangibly evident in the form of a major building program, was in progress. In the external environment, most notable was a public shift in attention from government fiscal restraint to the resuscitation of social services, curtailed over a five year period (Government documents). In higher education, the resuscitation included an expansion of educational opportunities, particularly aimed at those who were previously excluded because of gender, geographical location, aboriginal status, or disability. Thus, the presence of both a publicly acknowledged college historical background and a favourable political environment made change not only possible but also inevitable at Success Community College. The new president had a mandate for change that was charged by the college governing board with improving the public image of the college, expanding services in the community, and maintaining order and stability within the institution (Interviews with board member and administrators). 
College faculty, support staff, administrators, and board members were highly receptive to a new presidency (Extended conversations with faculty, support staff, and administrators). Their experiences with the former president, well-documented in internal college reports and communications, were mostly negative. The institution was described as neglected or abused in an approved motion of non-confidence in the senior administration publicized by the faculty union. Employee morale was characterized as dismal during this period by faculty union newsletters and an internal report (College Communication Report, 1986). As a consequence of this past, there were both high expectations for the new president and considerable latitude accorded to the new president in the exercise of presidential responsibilities. Not only were the expected outcomes of presidential succession activated at Success Community College but also an historical context, both on a social and political level and on an institutional level, provided an environment which could support the alterations expected during succession.

\section{Decision-making: Management and Governance Structures}

As noted by such organizational scholars as Mintzberg (1973), "administrators face pressures to act assertively, demonstrate power, and exert leadership" (Hart, 1991, p. 468). Leadership succession in an environment of internal turbulence and upheaval, as well as under conditions where there is negative publicity for the institution, could reasonably lead to a mandate for stability and tighter operational control within the institution. At Success Community College, not only the governing board but also college faculty wanted the conditions of instability to cease (Extended conversation with chair of presidential search committee, 1987). The new president set about to establish a decisionmaking process to respond to these demands, and this action involved fundamental change to management processes at Success Community College.

Initial actions by the president were directed against incumbent administrators and used as behavioural control mechanisms, first manifest in job descriptions, second in co-ordination of work through a quasi-matrix management system, and third through the establishment of a single formal committee of senior administrators for college decisions (Institutional documents). Within two months of arrival, the college president had eliminated the decision-making authority of individual administrators through the setting of standards of performance in job descriptions and by "the reduction of decision alternatives, coupled with coordination by plan...one of the most effective indirect control mechanisms" (Hasenfeld, 1983, p. 169). With tasks tightly connected, with a strong system of control, and with one authority figure, Success Community 
College lost many of its characteristics of a loosely-coupled system (Weick, 1976). Negotiated order (Strauss, 1988) disappeared; the performance of administrators was monitored; and rewards and sanctions in the form of potential promotions (a reorganization of the college administration was carried out a month later), in the allocation of resources, and in personal attacks by the president were attached to administrative behaviours (Conversations with senior administrators and executive assistant to the president).

A second action, or set of actions, included an official college reorganization and the initiation of an indoctrination program (Institutional documents, conversations with senior administrators). The reorganization was primarily the elevation of some administrators and the role limiting of others. This action served to reduce decision points, to balance power relationships, and to give internal college constituents the appearance of action carried out by the president, to conform to what Mintzberg (1973) sees as the manager's role: an "adaptive information manipulator(s) who favor[s] a stimulus-response milieu" (p. 171). In this case, the response by the president was to the events of the past, especially the loss of institutional control by the former president, which from the perspective of college constituents suggested inadequate performance by administrators. While some of these administrators were no longer employed by the college, such as the former president, the majority continued in their administrative roles. The new president had to convince college constituents that a new administration was in place, yet this new administration was composed with one exception of only one new college administrator - the president.

The program of indoctrination possessed several facets. One of these, the development of a team concept of administration, led to a series of meetings and workshops for the administrators and the use of external consultants--one to organize the senior administrators within a context of unified goals and behaviours, and another to provide an action plan for management development based upon a survey questionnaire completed by all administrators. While neither of these activities led to tangible outcomes, in the form of policies, structures, processes, they did have several indoctrination functions. They exposed those who were not faithful or loyal to the president, either by encouraging the vocalization of personal views in meetings or by documenting negative criticism in the survey questionnaire. These gatherings provided the president with a forum where the sole authority figure - that individual who initiated and presided over the process and who determined directions and subsequent actions - was the president. Quickly, the administrators learned that 'team' had the connotation of behavioural conformity, lack of critical perspective, and service to the president. Those who were not loyal to the team were either chastised and threatened by 
the president or warned by those who reported directly to the president. The chain of command was also a chain of control maintained by verbal threats, reprimands, and additional work assignments (Conversations with senior administrators).

Decision-making at Success Community College was a process whereby the president unilaterally concluded that an action was required. The quasimatrix management system was more an appearance than a reality as the president insisted on personal approval for all decisions. Senior administrators who reported to the president advised the president on matters which were defined as relevant by the president. College decisions were controlled by the president. Those decisions which required approval by the college board of governors were taken by the president to the board, and the board followed the advice of the president. The board too was managed by the president who communicated frequently with board members and assigned them work on behalf of the college, such as lobbying government officials.

Management and governance at Success Community College were indistinguishable from one another, and that tradition of many higher education institutions where the faculty are largely responsible for identifying and solving educational issues, and even acting upon their decisions, was absent from Success Community College. College committees were organized and operated by administrators and all responsible administrators reported either to the president or to an administrator who reported to the president. The president reserved the right to overturn decisions which were personally unsatisfactory. A key component of the job functions of these administrators was the management of academically related processes such as program development and review, educational planning, and faculty performance evaluation. These, too, were indirectly controlled by the president by virtue of the interference of the president in all levels of management, such as the president informing the responsible administrator at the outset that a program should be evaluated negatively. (Administrative meeting notes, conversations with senior and mid-level administrators and faculty).

A mechanism to support this approach to decision-making was a system of communication that included college meetings for the entire college with the president, letters from the president to all college employees, a college newsletter, constant information dissemination to the college board by the president, and directives from the president to senior administrators to ensure that all subordinates had information and passed on that information (Institutional documents). In addition, a college department was established, initially with a single administrator and a part-time support staff employee to manage communications and disseminate information, as well as to market the college externally. 
Within a four year period, this department developed into a large enterprise with an annual budget of approximately a half a million dollars and over eight employees (Institutional documents). Promotion and marketing of a college image and the public views of the president were central communication functions of Success Community College.

\section{Cultural Shift}

The study of organizational culture in higher education has indicated that beliefs, values, and ideologies held by organizational participants contribute to both a shared pattern of behaviours and common interpretations of behaviour (Bensimon, 1989; Chaffee \& Tierney, 1988; Cooper \& Kempner, 1991; Tierney, 1988). While organizations may be fragile (Cooper \& Kempner, 1991), culture provides a cohesive force, for example, anchoring the present to the past (Bolman \& Deal, 1985). It has been suggested (Horst, 1989) that to change an organization, or at least to support and sustain changes within an organization, there must be a modification to the existing culture or cultures.

Change efforts directed by the president at Success Community College, that is change which is fundamental (Smith, 1982) and institutionalized (Goodman \& Dean Jr., 1982), could be viewed as approaching cultural modification--an alteration to the pattern of behaviour of institutional participants and to the interpretations of behaviour, even to the beliefs, values, and ideologies of organizational members. A desired cultural shift at Success Community College was signaled by the president through a change both to communications and to operations, an alteration of "how things happen" (Tierney, 1988, p. 20). Such changes involved alteration to existing relationships, both between people and other people and people and their work (Conversations with administrators). In this process of change (Smith, 1982), the new constructions (i.e., of new relationships) were also a process of destruction (i.e., of existing relationships). "Cultural change in organizations requires the conscious destruction of old processes and structures, as well as the institutionalization of new processes and structures" (Cameron \& Ettington, 1988, p. 388). In the change of the management structure of Success Community College, for example, the president formalized working relationships between administrators, ensuring that they were following the objectives of the president in their actions (Institutional documents, conversations with administrators). As well, administrators were burdened with a workload that did not permit time for informal interaction. Personal relationships became strained as a chain of command approach to management and its attendant behaviours such as displays of deference to superiors became an established practice (Conversations with administrators). 
The process of change at Success Community College and the suggestion of a resultant cultural shift are noted in the interpretations of institutional participants. Five former academic administrators at Success Community College described and analyzed their experiences and perceptions during the process of change. Their perceptions and analyses are complementary. They share the view that their work changed dramatically, and, in their judgement, the single change agent was the president. One senior administrator analysed the process of change as deliberate, even maniacal:

Changes to the institution involved controls over attitudes and behaviours of the administrators. In an effort to control every aspect of the college, the president oversaw development of policy manuals, planning documents, and personally sourced employees to satisfy curiosity. In particular, hirings and budgets were carefully controlled by the chief executive officer. There was a grand scheme to control the institution--the chief executive officer commandeered the entire institution...The president tried to drive others nuts. (College administrator)

Another administrator, a mid-level manager, noted that "the institution changed completely, especially in how the administration worked".

The college was efficient but lacked innovation and creativity. There was no freedom. The administrators were terrorized, responding only to the chief executive officer and their interpretations of the chief executive officer's desires. Everything at the college was undercover; people were fearful because of job security...Because the chief executive officer threatened others' livelihood they had to comply...no one performed for the college or did what they thought was good. (College administrator)

As a whole, the five administrators describe an environment where as administrators their relationships with other administrators and with their work altered dramatically. One noted that former college goals and objectives were abandoned and replaced by the objectives of the president. They indicated a disintegration of the administrative group, a destruction of trust among administrators, and a professional detachment from their work (e.g., "going through the motions").

It has been argued by organizational theorists (Ouchi \& Wilkins, 1985) that cultural change in an organization is a traumatic event and those involved are under threat to abandon their way of coping with organizational life. The five college administrators characterize their experiences as "negative", "dissatisfying", and "unrewarding": "the worst experience of my life", claimed one administrator. They describe an environment where they lost both their dignity and 
their effectiveness, some becoming "angry", "frustrated", and another an "emotional wreck". At Success Community College, change for these five administrators was both dramatic and disturbing where behavioural processes as well as motivations were transformed - with old expectations and patterns replaced. One mid-level administrator analyzed this condition:

The institution became a much less open, friendly, compassionate, pleasant and rewarding place to work. Suspicion replaced peer support and friendliness...The overall environment was perceived by many to be most unharmonious...Consultation on many matters was subject to form and not substance[,]...rarely was much attention paid to the results. Many people were reluctant to speak out on topics and kept their opinions and ideas to themselves." (College administrator)

These administrators conclude that the role of the president in these changes was quintessential. They view the actions of the president as almost totally negative. On a professional level, they see their college as turned "upside down" by the president, where distrust, fear, manipulation, and authoritarian control define institutional life. On a personal level, their lives were affected significantly, and the subjects described the consequences of their employment at Success Community College as follows: move to a "better job", "left college", "forced to leave", "retire[d]", and "resigned". (It should be noted that two other administrators, who terminated their employment with the college prior to the initiation of this study, and who were in similar positions to the five administrators who participated in this study, refused to complete the survey questionnaire. One preferred to "leave the past behind"; the other did not want to commit responses to written expression, uncomfortable with a potential for public disclosure, in the event of a civil suit.)

Just prior to the arrival of the new president to Success Community College, these administrators welcomed change and saw the president as a catalyst for a "new era", an individual who would "resolve problems which emerged under two previous presidents". Within several months after the arrival of the president, these same administrators observed examples of the change they would experience in the subsequent months and years.

The first example of the new style was the method of dealing with the only woman in senior management--gross mismanagement with total disregard for the individual. (College administrator)

Slowly a pattern emerged--emphasis on negatives; only one person had the correct/right answers and views. (College administrator)

[A]s time went on and the character and management style of the new president became more obvious I had increasing unease and discomfort. (College administrator) 
The promise of cultural shift was implied if not stated by the behaviours and actions of the president. This shift in the ways institutional members work and interact with each other is clearly acknowledged by the five administrators who describe their experiences and perceptions. By the end of the third year after the arrival of the president, these perceptions were acknowledged and even shared by support staff and by faculty whose employment at Success Community College preceded the arrival of the president and who had more than superficial or formal interaction with the president (Conversations with faculty and support staff). This judgement that the president had significantly changed institutional life corresponded to the completion of the first permanent facility for the college.

All of the five administrators noted above preceded the president in their positions at Success Community College; all were outlived in their careers at Success Community College by the president. It is evident from their observations that their beliefs and values, as well as their ideologies, were incompatible with the practices of the president. All were replaced either through new hirings or through reorganization of their areas of responsibility, excepting one administrator. In this case, the actions of the president in reorganizing the management structure resulted in a position elimination and the demotion of an administrator. Instead of accepting this demotion, the administrator resigned (as did one board member as a consequence of a dispute with other board members and the president over this reorganization, and the demotion of the administrator). The shift in institutional culture, in "how we do things around here" (Tierney, 1988, p. 20), led to personal and career change for administrators as well as to organizational change for Success Community College. (Conversations with administrators and board member)

\section{Outcomes of Organizational Change at Success Community College}

A shift from loose-coupling (Weick, 1976), where decisions are often not implemented and if implemented have uncertain consequences (Hasenfeld, 1983), to tight-coupling in managerial control and action is suggested to result in several conditions in higher educational institutions. Hasenfeld (1983) suggests that loose-coupling accommodates different moral and ideological systems within the organization, minimizing potential conflict. Tight-coupling reduces decision alternatives, "circumscribes workers' discretion and specifies rules workers must follow in making...decisions" (Hasenfeld, 1983, p. 169). Weick (1976) indicates that loosely-coupled systems are resilient structures, and 
in such systems symbolic functions of leadership (Smircich \& Morgan, 1982) are more critical than formal, organizational roles (Pfeffer, 1981). A shift to tight-coupling may reduce the significance of symbolic action and heighten emphasis upon structures, actions, and outcomes. This may indicate that tangible organizational outcomes such as enrolment increases are goals compatible with leaders who rely upon tight-coupling. Alternately, as a consequence of organizational change, actions which were formerly significant no longer are and other actions acquire new significance.

The organizational changes at Success Community College, reviled by the five administrators in this study, are reflected in the institutional emphasis upon tight-coupling. The behavioural controls upon the administrators paralleled organizational actions such as policy development, systematic pursuit of resources, emphasis upon the creation and maintenance of a public image, considerable efforts to increase student enrolments, and intense political lobbying, both internally and externally, by the president. For example, student enrolments rose by over $40 \%$ during a four year period of this presidency. Also, the budget for the college rose accordingly (Institutional and government documents). These behaviours could be seen to characterize the institution, objectively, as a successful enterprise, one improving quantitatively in its pursuit and acquisition of more: more physical space, more employees, more students, more financial resources, and more publicity. This growth or success of the college, no doubt, sustained organizational change and supported presidential control.

In the competition between value systems and ideologies in the community college, the case of Success Community College indicates that it is behavioural change and control which alter "how we do things around here" (Tierney 1988, p. 20). This competition subsequently led to a change in the employment status of those administrators who did not conform to the expectations of the president either behaviourally or ideologically. It led as well to the elimination of faculty participation in institutional decision-making (Conversations with administrators and faculty). Administrators were charged with ensuring that college decisions were those acceptable to the president, and the administrators were compelled to control and manipulate the actions and recommendations of faculty. The imperative for control over faculty was clear to all administrators (Conversations with administrators). The pressure to conform, as noted by the administrators, was severe with dire consequences for those who did not meet the expectations of the president. Unable or unwilling to impede the actions of the president, the five administrators, who were highlighted in a previous section, (and at least a dozen other administrators who severed their employment connection and left the college during the same period) could not preserve their 
administrative positions as they were either unable or unwilling to conform to expected behaviours; their views were not compatible with the espoused ideology of the president.

Organizational change at Success Community College appears as a fundamental alteration to college structure, processes, and administrative personnel. On another level, change in organizational life--including the values that guided behaviours and the rituals which followed behaviours--affected how college members interacted. For example, new rituals and ceremonies were initiated by the president and former practices were abandoned. New processes and structures at Success Community College reflected the personal values of the president, and presidential control over the institution indicates that the president was indeed successful in providing organizational stability and in "fram[ing] and defin[ing] the reality of others" (Smircich \& Morgan, 1982, p. 258). Those administrators who did not accept the reality articulated and defined by the president were victimized by the president, and the majority of these eventually resigned, replaced by those who would acquiesce to the demands of the president. Others, including faculty and support staff, worked within an organizational context where the objectives and the priorities of the president were the only permissible topics of conversation and acceptable work assignments (Conversations with faculty, administrators, and staff; interviews with administrators). Their organizational reality was thus framed and defined.

The departure of the president from Success Community College was effected not by faculty nor even directly by disaffected administrators, but by the governing board (Newspaper accounts, conversations with administrators and faculty). An institutional self-study report, including the report of an external audit committee, led to an evaluation of presidential performance. After working with a governing board, largely intact from 1987-1991, the president subsequently encountered new board membership. As one faculty respondent noted, the "self-study pointed a few fingers and the new board" which was not composed of the president's "creatures...decided to evaluate" the president. At that "point it was all over". As noted elsewhere (Levin, 1991), the relationship of board and president is a determining factor of the performance of the community college president. When a board and president do not share values and preferences, the board-president relationship will not likely be an harmonious relationship. Walker (1979) indicates that less effective administrators react with aggressive behaviour when under attack. At Success Community College, once the board began its review of presidential performance and signaled that they were not enamored with the performance of the president, the hostility the president harboured for the board surfaced and the performance of the president 
in the eyes of the board plummeted (Conversation with acting college president, 1994). An investigation followed, and the investigators surveyed faculty and both former and present administrators, concluding that the performance of the president was damaging to the institution. In the Fall of 1993, the board asked the president to resign (Newspaper accounts, conversations with administrators, 1993 and 1994).

According to the acting president of the college, the former president "brutalized" people and "damaged" the institution. Recovery, he reported, would be slow. Nonetheless, the sense of relief by all after enduring dramatic change to college processes and behaviours provided the impetus for recovery (Conversation with acting president, 1994).

\section{Conclusion}

In spite of scholarship that provides some conceptual clarity about how four year colleges and universities work (Bergquist, 1992; Birnbaum, 1988), there are few lucid analyses of change in action and little clarity about organizational functioning of community colleges. Cohen and Brawer (1987) note that while there is a considerable body of literature on governance and administration, that literature is largely consumed with prescriptions and advice. The examination and understanding of both the forces of change and the leadership that initiates and influences change are limited.

While higher education scholars and practitioners articulate the need for organizational change, not all change has positive outcomes. This study suggests that organizational change may have consequences which are destructive. At Success Community College, organizational change managed by the president was a dramatic transformation to how the college functioned. The president as a successful change agent was the purveyor of suffering to other administrators, and the achievement of organizational goals was at the expense of individual well-being. While the college enlarged, improved its public image, and acquired more resources, it possessed many of the characteristics of an autocracy (Mintzberg, 1983). The president was successful in silencing the faculty, in controlling the board of governors, and in achieving compliance from administrators. Such actions may suggest that the president altered organizational culture and provided transformational leadership to Success Community College.

Studies of transforming leaders (e.g., Bass, 1985; Deal \& Kennedy, 1985; Kanter, 1983) characterize such leaders as positive reinforcers (Deal \& Kennedy, 1985) and inspirational (Kanter, 1983) and charismatic leaders who 
arouse enthusiasm in followers (Bass, 1985). While there is considerable evidence suggesting that the president at Success Community College transformed that institution, the outcomes, certainly to the administrative group identified in this study, indicate that leadership was a malignant force. The accounts of transforming leaders such as the president in this study are missing in organizational literature. Does this suggest that the president of Success Community College is an anomaly in a leadership role in higher education? Are all other transformational leaders positive forces in organizational life?

This case may suggest that the presence of what is characterized as a malignant force by organizational participants is associated with the functioning of the community college. Birnbaum (1988) and Bergquist (1992) suggest that community colleges may have structures, processes, and cultures which are more bureaucratically and hierarchically managed than four-year colleges and universities. These institutions possess traditions such as senate bodies, the publication imperative, and a firmly entrenched system of promotions and tenure; their governance structures enable faculty to have more control or influence over managerial action than that found at community colleges. At community colleges, faculty rights are negotiated in unionized environments and meted out by administrators in non-unionized institutions. Managerial authority is more commonly vested in administrators and governors than in faculty. Indeed, the proclaimed qualities of community colleges, such as adaptability and flexibility (Levin \& Dennison, 1989) may make these institutions prey to irrational and autocratic (Mintzberg, 1983) management, or at least organizational instability. The potential for organizational instability in the community college is portrayed in a recent case study (Cooper \& Kempner, 1991).

The exceptional nature of this case is that it presents several contrasting perspectives to studies of higher education institutional leadership and to accounts of organizational change. Organizational life at Success Community College is far different not only from those institutions described in the literature on model institutions (e.g., Clark, 1970; Kuh, Schuh, Whitt, et al., 1991), but also from those assumed to exist in the literature on organizational management and change (e.g., Beckhard \& Pritchard, 1992; Bolman \& Deal, 1985). The descriptions by Morgan (1986) of organizations as instruments of domination or as psychic prisons may provide more appropriate characterizations and explanations of the functioning of some educational institutions than that found in the prescriptions and appeals for organizational change and transformation. The case of Success Community College indicates that not all organizational change has a happy ending and that those who promote and facilitate the change process for community colleges should consider all potential outcomes of change, including the victimization of organizational participants. 


\section{A Final Note}

Both observers of this community college and reviewers of the accounts of this case expressed bewilderment with the organizational members who permitted the previously cited behaviours and actions of the president of Success Community College. These observers and reviewers were astonished that a community college president with these attributes could "last for long". Six years passed before the behaviours and actions documented in this investigation halted at Success Community College. The question of why is not unreasonable. The answer does not come readily and may require further research; however, the controlling actions of the president described earlier cannot be underestimated. And the perceptions of the largest group of employees, the faculty, may have been dulled by their comforts, as expressed by one faculty member.

The place worked well. Students were better served than previously.

There were no strikes or major scandals, The toilets flush and roof leaks are reparable."

\section{References}

Bass, B. (1985). Leadership: Good, better, best. Organizational Dynamics, (Winter), 2640.

Beckhard, R. \& Pritchard, W. (1992). Changing the essence: The art of creating and leading fundamental change in organizations. San Francisco: Jossey-Bass Inc., Publishers.

Bensimon, E. (1991). The social processes through which faculty shape the image of a new president. Journal of Higher Education, 62, 637-660.

Bergquist, W. (1992). The four cultures of the academy. San Francisco: Jossey-Bass Inc., Publishers.

Birnbaum, R. (1988). How colleges work. San Francisco: Jossey-Bass Inc., Publishers.

Bolman, L., \& Deal, T. (1985). Modern approaches to understanding and managing organizations. San Francisco: Jossey-Bass Inc., Publishers.

Brint, S., \& Karabel, J. (1989). The diverted dream: Community colleges and the promise of educational opportunity in America, 1900-1985. New York: Oxford University Press.

Burgess, R. (1984). In the field: An introduction to field research. Boston: George Allen and Unwin.

Cameron, K., \& Ettington, D. (1988). The conceptual foundations of organizational culture. In J. Smart (Ed.), Higher education: Handbook on theory and research, Volume 4 (pp. 356-396). New York: Agathon Press.

Chaffee, E., \& Tierney, W. (1988). Collegiate culture and leadership strategies. New York: American Council on Education and Macmillan Publishing Company. 
Clark, B. (1970). The distinctive college: Antioch, Reed and Swarthmore. Chicago: Aldine.

Cohen, A., \& Brawer, F. (1982). The American community college. San Francisco: Jossey-Bass Inc., Publishers.

Cohen, A., \& Brawer, F. (1987). The American community college. San Francisco: Jossey-Bass Inc., Publishers.

Cooper, J. ,\& Kempner, K. (1991). Lord of the Flies community college: A case study of organizational disintegration. Unpublished paper.

Cross, K.P. (1985). Determining missions and priorities for the fifth generation. In W. Deegan, D. Tillery, et al. (Eds.), Renewing the American community college, pp. 34-50. San Francisco: Jossey-Bass Inc., Publishers.

Deal, T., \& Kennedy, A.A. (1985). Corporate cultures. Reading, MA: Addison Wesley.

Deegan, W., Tillery, D., \& Melone, R. (1985). The process of renewal: An agenda for action. In W. Deegan, D. Tillery, et al. (Eds.), Renewing the American community college, pp. 313-324. San Francisco: Jossey-Bass Inc., Publishers.

Dennison, J., \& Gallagher, P. (1986). Canada's community colleges. Vancouver: University of British Columbia Press.

Erickson, F. (1986). Qualitative methods in research on teaching. In M.C. Wittrock (Ed.), Handbook of research on teaching, pp. 119-161. New York: MacMillan Publishing Company.

Goodman, P., \& Dean Jr., J. (1982). Creating long-term organizational change. In P. Goodman et al. (Eds.), Change in Organizations (pp. 226-279), San Francisco: Jossey-Bass Inc., Publishers.

Hart, A. (1991). Leader succession and socialization: A synthesis. Review of Educational Research, 61 (Winter), 451-474.

Hasenfeld, Y. (1983). Human service organizations. Englewood Cliffs, New Jersey: Prentice Hall, Inc.

Horst, B. (1989). Organizational culture and change. In K. Hughes \& D. Conner (Eds.), Managing change in higher education: Preparing for the 21st century, (pp. 67-78). Washington, DC: College and University Personnel Association.

Kanter, R. (1977). Men and women of the corporation. New York: Basic Books.

Kanter, R. (1983). The change masters. New York: Simon and Schuster.

Kempner, K. (1991). The community college as a marginalized institution. Unpublished paper.

Kuh, G., Schuh, J., Whitt, E., et al. (1991). Involving colleges. San Francisco: JosseyBass Inc., Publishers.

Levin, J. (1991). The importance of the board-president relationship in three community colleges. Canadian Journal of Higher Education, 2I(2), 63-69.

Levin, J. (1992). College transformation? A critical examination of a study of management of a community college. Paper presented at the annual meeting of the Canadian Society for the Study of Higher Education, Charlottetown, Prince Edward Island.

Levin, J., \& Dennison, J. (1989). Responsiveness and renewal in Canada's community colleges: A study of change in organizations. The Canadian Journal of Higher Education, $19(2), 41-57$. 
Merriam, S. (1988). Case study research in education: A qualitative approach. San Francisco: Jossey-Bass Inc., Publishers.

Miles, M., \& Huberman, A.M. (1984). Qualitative data analysis. Beverly Hills: Sage Publishing.

Mintzberg, H. (1973). The nature of managerial work. New York: Harper and Row Publishers.

Mintzberg, H. (1983). Power in and around organizations. Englewood Cliffs, NJ: Prentice Hall, Inc.

Miskel, C., \& Cosgrove, D. (1985). Leader succession in school settings. Review of Education Research, 55, 87-105.

Morgan, G. (1986). Images of organization. Beverly Hills: Sage Publications.

Ouchi, W., \& Wilkins, A. (1985). Organizational culture. Annual Review of Sociology, $11,457-483$.

Pfeffer, J. (1981). Management as symbolic action: The creation and maintenance of organizational paradigms. Research in Organizational Behavior, 3, 1-52.

Smircich, L., \& Morgan, G. (1982). Leadership: The management of meaning. The Journal of Applied Behavioral Science, 18(3), 257-273.

Smith, K. (1982). Philosophical problems in thinking about organization change. In P. Goodman et al. (Eds.), Change in Organizations, pp. 316-374. San Francisco: Jossey-Bass Inc., Publishers.

Strauss, A. (1988). Negotiations: Varieties, contexts, processes, and social order. San Francisco: Jossey-Bass Inc., Publishers.

Tierney, W. (1988). The web of leadership. Greenwich, CT: JAI Press.

Tillery, D., \& Deegan, W. (1985). The evolution of two-year colleges through four generations. In W. Deegan \& D. Tillery, et al. (Eds.), Renewing the American community college, pp. 3-33. San Francisco: Jossey-Bass Inc., Publishers.

Walker, D. (1979). The effective administrator. San Francisco: Jossey-Bass Inc., Publishers.

Weick, K. (1976). Educational organizations as loosely coupled systems. Administrative Science Quarterly, 21 (March), 1-19. 